\title{
HLA types in patients with rheumatoid arthritis developing leucopenia after both gold and sulphasalazine treatment
}

\author{
HENNING BLIDDAL, ${ }^{\text {BIRTE EIBERG, }}$, PEKKA HELIN, 3 AND \\ ARNE SVEJGAARD
}

From the ${ }^{1}$ Department of Rheumatology, Bispebjerg Hospital, Copenhagen; the ${ }^{2}$ Clinic of Rheumatology, Lyngby; the ${ }^{3}$ Department of Rheumatology, Glostrup Hospital; and the ${ }^{4}$ Tissue Typing Laboratory, Department of Clinical Immunology, University Hospital, Copenhagen, Denmark

SUMmARY HLA types, especially HLA-DR3, are associated with the development of toxic reactions in patients with rheumatoid arthritis after treatment with gold or D-penicillamine. In this study, after treatment with sulphasalazine, leucopenia was observed in three patients, who all had a history of leucopenia after previous gold treatment. The HLA types of these patients did not include HLA-DR3; the two patients developing mild leucopenia had HLA-DR2 and the one developing agranulocytosis had HLA-DR4.

During clinical trials of disease modifying antirheumatic drugs an overlap has been observed between groups of patients with toxic reactions to different drugs-for example, gold and D-penicillamine. ${ }^{12} \mathrm{~A}$ genetic predisposition to the haematotoxic reactions to these two drugs has been suggested, ${ }^{3}$ in accordance with observations of a general tendency towards association between certain HLA types and toxic reactions to antirheumatic drugs.

We introduced sulphasalazine to more than a 100 patients with rheumatoid arthritis and observed neutropenic reactions in only three, all of whom had experienced similar previous reactions to gold. ${ }^{5}$

Accepted for publication 21 October 1988.

Correspondence to Dr Henning Bliddal, Department of Rheumatology, Bispebjerg Hospital, DK-2400 Copenhagen NV, Denmark.

\section{Patients and methods}

\section{PATIENTS}

All three patients had classical rheumatoid arthritis at the time of treatment with sulphasalazine. Table 1 shows the principal clinical data.

HLA TYPING

HLA-A, B and C typing and HLA-DR typing were performed as described by Jacobsen $e t$ al. ${ }^{6}$ Table 2 gives details of the three patients.

Table 2 HLA types of the three patients developing leucopenia after both gold and sulphasalazine treatment

\begin{tabular}{ll}
\hline $\begin{array}{l}\text { Patient } \\
\text { No }\end{array}$ & HLA types \\
\hline 1 & A1,2; B27,39; Cw2; DR2,w6,w52; DQw1 \\
2 & A3,23; B7,44; Cw4; DR2,7,w53; DQw1,w2 \\
3 & A1,3; B7,17; Cw2w6; DR4,7,w52,w53; DQw2
\end{tabular}

Table 1 Clinical data of the three patients developing leucopenia after both gold and sulphasalazine treatment

\begin{tabular}{|c|c|c|c|c|c|c|c|c|c|c|}
\hline \multirow[t]{2}{*}{$\begin{array}{l}\text { Patient } \\
\text { No }\end{array}$} & \multirow[t]{2}{*}{ Sex } & \multirow[t]{2}{*}{$\begin{array}{l}\text { Age } \\
\text { (years) }\end{array}$} & \multirow{2}{*}{$\begin{array}{l}\text { Rheumatoid } \\
\text { arthritis } \\
\text { onset (date) }\end{array}$} & \multirow{2}{*}{$\begin{array}{l}\text { Gold } \\
\text { treatment } \\
\text { (date) }\end{array}$} & \multirow{2}{*}{$\begin{array}{l}\text { Dose of } \\
\text { gold before } \\
\text { leucopenia } \\
\text { (mg/day) }\end{array}$} & \multirow{2}{*}{$\begin{array}{l}\text { Sulphasalazine } \\
\text { treatment } \\
\text { (date) }\end{array}$} & \multirow{2}{*}{$\begin{array}{l}\text { Dose of } \\
\text { sulphasalazine } \\
\text { at leucopenia } \\
\text { (mg/day) }\end{array}$} & \multicolumn{2}{|c|}{$\begin{array}{l}\text { Leucocyte counts } \\
\left(10^{\circ} /\right)\end{array}$} & \multirow{2}{*}{$\begin{array}{l}\text { Recovery } \\
\text { time } \\
\text { (days) }\end{array}$} \\
\hline & & & & & & & & Before & After & \\
\hline \multirow[t]{2}{*}{1} & $\mathbf{F}$ & 31 & 1973 & (1973) & & & & & & \\
\hline & & & & 1982 & 1010 & 1985 & 500 & $6 \cdot 4$ & $1 \cdot 2$ & 14 \\
\hline 2 & $\mathbf{F}$ & 55 & 1979 & 1979 & 120 & 1986 & 2000 & $4 \cdot 3$ & 1.2 & 9 \\
\hline 3 & $\mathbf{F}$ & 51 & 1981 & 1981 & 500 & 1986 & 1000 & $5 \cdot 1$ & 0.5 & 21 \\
\hline
\end{tabular}




\section{Case reports}

CASE 1

A woman born in 1942 developed rheumatoid arthritis in 1973. Within a year she went into remission after receiving $1300 \mathrm{mg}$ of aurothiomalate. The rheumatoid arthritis relapsed in 1982, and for a second time remission was obtained with aurothiomalate treatment, which, however, had to be withdrawn at $1010 \mathrm{mg} /$ day because of leucopenia (a reduction from 8.9 to $2.4 \times 10^{9} / 1$ ). In 1985 the rheumatoid arthritis relapsed again, and this time the patient was treated for two weeks with sulphasalazine $500 \mathrm{mg} /$ day. Leucocyte counts fell from 6.4 to $1.2 \times 10^{9} / 1$, and upon withdrawal of sulphasalazine slowly normalised over 14 days. No clinical effect of the leucopenia was observed. The only other drug given during this period was aspirin, which was continued in the same dosage. Blood platelets and haemoglobin did not change during observation.

\section{CASE 2}

A woman born in 1924 developed rheumatoid arthritis in 1979, and treatment with aurothiomalate was started but had to be withdrawn after three weeks at $120 \mathrm{mg} /$ day owing to leucocyte depression (a fall from 7.2 to $2.9 \times 10^{9} / 1$ ). Over the following years the rheumatoid arthritis was active despite alternating treatment with azathioprine, D-penicillamine, cyclophosphamide, and prednisone.

In 1986 treatment with sulphasalazine was introduced in slowly increasing doses from 500 to $2000 \mathrm{mg} /$ day. A fall in leucocytes from 4.3 to $1.2 \times 10^{9} / 1$ was observed, which upon withdrawal of sulphasalazine normalised in nine days without clinical symptoms. Other drug treatment included prednisone and D-penicillamine, which was unaltered during this period. Blood platelets and haemoglobin were unchanged.

\section{CAS E 3}

A woman born in 1930 developed rheumatoid arthritis in 1981, and treatment with aurothiomalate was started but withdrawn at $500 \mathrm{mg} /$ day after a fall in leucocytes from 8.0 to $3.3 \times 10^{9} /$. The rheumatoid arthritis remained active during the following years despite treatment with D-penicillamine.

In 1986 non-steroidal anti-inflammatory drugs were discontinued (upon request of the patient) and treatment with sulphasalazine was started at 1000 $\mathrm{mg} /$ day. After 14 days a severe bone marrow depression developed with a reduction in leucocyte counts from $5 \cdot 1$ to $0 \cdot 5 \times 10^{9} / 1$ (granulocytes 0 , blood platelets $110 \times 10^{9} / 1$, and haemoglobin $\left.82 \mathrm{~g} / \mathrm{l}\right)$. The patient was transferred to the department of infec- tious medicine and treated symptomatically. T品 bone marrow recovered in 21 days and leucocyte counts normalised. The patient recovered withot late sequelae.

\section{Discussion}

Sulphasalazine is generally regarded as a fairly safie disease modifying antirheumatic drug with few adverse reactions apart from gastrointestinal symptoms. ${ }^{78} \mathrm{~A}$ bone marrow depression depende on dose does occur in a proportion of patients More severe idiosyncrasies, such as haematotoxic reactions, may occur, however, as in our thing patient. Our three patients had all experienced of mild subclinical leucopenia with gold treatment, but two of these patients had subsequently receives D-penicillamine without any adverse effects.

Because of persistently active rheumatoid arthritis sulphasalazine was chosen as a secondary singe disease modifying antirheumatic drug for one patient (No 1) and for combined treatment witc D-penicillamine in two patients (Nos 2 and 3).

The leucopenia in patients 1 and 2 was subclinica and readily reversible, indicating a toxic effect of sulphasalazine, presumably related to the sulphàpyridine component of the drug. ${ }^{10}$ In contrast, the reaction in patient 3 was severe with a longlastipg bone marrow depression.

A tendency towards adverse reactions has be $\overrightarrow{\vec{n}}$ seen in patients treated first with injectable gold and then with D-penicillamine. ${ }^{12}$ A similar observatio for sulphasalazine and other preceding disease modifying antirheumatic drugs has not been profviously reported. Our three patients with leucopentia were the only cases in a series of more than 190 patients treated with sulphasalazine during the sarige period, and the correlated previous reaction to gowd cannot be explained by chance considering the veळy rare occurrence $(<3 \%)$ of leucopenia after these two drugs. A genetic predisposition is thus stspected.

The HLA types were DR2 in the two patiens with a mild neutropenia and DR4 in the patient with agranulocytosis. There is no published information about the relation between genetic markers agd adverse effects to sulphasalazine, but an analogy with gold might be predicted. After gold treatmeg t an association between HLA-DR3 and toxic reaetions in general, including haematotoxic reactiong, has been reported. ${ }^{3411}$ In one study HLA-DR2 (ब्बs in two of our cases) was implicated as a marker $\overrightarrow{\mathrm{g}} \mathrm{f}$ side effects. ${ }^{4}$ The occurrence of HLA-DR4 is not 50 informative as it is present in most patients with rheumatoid arthritis; in a study by Aaron et al, however, this antigen was associated with sevese 
bone marrow reactions to gold (as in case 3) but not with milder neutropenia.

In conclusion, a shared genetic predisposition of bone marrow reactions may exist between the different disease modifying antirheumatic drugs. Thus a history of leucopenia after gold treatment indicates extreme caution during subsequent treatment with sulphasalazine. It is possible that certain HLA factors may contribute to leucopenia, but more studies are needed for clarification.

\section{References}

1 Dodd M J, Griffiths I D, Thompson M. Adverse reactions to Dpenicillamine after gold toxicity. $\mathrm{Br} \mathrm{Med} J$ 1980; 280: 1498-500.

2 Smith P J, Swinburn W R, Swinson D R, Stewart I M. Influence of previous gold toxicity on subsequent development of penicillamine toxicity. Br Med J 1982; 285: 595-6.

3 Speerstra F, Reekers P, van de Putte L B A, Vandenbroucke J P. HLA associations in aurothioglucose-and D-penicillamineinduced haematotoxic reactions in rheumatoid arthritis. Tissue Antigens 1985; 26: 35-40.

4 Panayi G S, Wooley P, Batchelor J R. Genetic basis of rheumatoid disease: HLA antigens, disease manifestations, and toxic reactions to drugs. $\mathrm{Br}$ Med J 1978; ii: $1326-8$.

5 Bliddal H, Eiberg B, Helin P. Gold-induced leucopenia may predict a similar adverse reaction to sulphasalazine. Lancet 1987 ; i: 390.

6 Jacobsen B K, Morling N, Platz P, Ryder L P, Thomsen M, Svejgaard A. HLA-DR phenotype and HLA-B,DR haplotype frequencies in 704 unrelated danes. Tissue Antigens 1981; 18: 270-5.

7 Peppercorn M A. Sulphasalazine, pharmacology, clinical use, toxicity and related new drug development. Ann Intern Med 1984; 101: 377-86.

8 Bax D E, Amos R S. Sulphasalazine: a safe, effective agent for prolonged control of rheumatoid arthritis. A comparison with sodium aurothiomalate. Ann Rheum Dis 1985; 44: 194-8.

9 Farr M, Symmons D P M, Blake D R, Bacon P A. Neutropenia in patients with inflammatory arthritis treated with sulphasalazine. Ann Rheum Dis 1986; 45: 761-4.

10 Pullar T, Hunter J A, Capell H A. Which component of sulphasalazine is active in rheumatoid arthritis? $\mathrm{Br} \mathrm{Med} \mathrm{J} \mathrm{1985;}$ 290: 1535-8.

11 Coblyn J S, Weinblatt M, Holdsworth D, Glass D. Goldinduced thrombocytopenia. Ann Intern Med 1981; 95: 178-81.

12 Aaron S, Davis P, Bertouch J. HLA-DR antigens in goldinduced neutropenia. Arthritis Rheum 1986; 29: 1515-7. 